\title{
Usefulness of PCR to Mycobacterium Tuberculous and Nontuberculous Mycobacteria from Paraffin-embedded Tissues
}

\author{
Yeon-Il Choi ${ }^{1}$ and Hye-Young $\mathrm{Kim}^{2}$ \\ ${ }^{1}$ Department of Clinical Pathology, Inha University Hospital, Incheon 400-711, Korea \\ ${ }^{2}$ Department of Clinical Laboratory Science, Shinsung University, Dangjin 343-861, Korea
}

\begin{abstract}
The purpose of this study was to evaluate the clinical utility of TB/NTM PCR by comparing the results of TB PCR to detect Mycobacterium tuberculous (MTB) and nontuberculous mycobacteria (NTM) from paraffin-embedded tissue specimens. A total of 60 cases were tested using TB PCR and TB/NTM PCR. The MTB and NTM rate of TB/NTM PCR was $84.2 \%(16 / 19), 10.5 \%(2 / 19)$ in TB positive of TB PCR. The NTM rate of TB/NTM PCR was 29.3\% (12/41) in TB negative of TB PCR. Fourteen different species of NTM were identified, the common isolate was M. gordonae (21.4\%), M. avium (14.3\%), M. ulcerans (7.1\%), M. interjectum (7.1\%), M. gilvum (7.1\%), M. fortuitum (7.1\%), M. mucogenicum (7.1\%). The rare species identified were $M$. farcinogenes $(7.1 \%), M$. tokaiense (7.1\%). Therefore, TB/NTM PCR is useful to differentiate MTB and NTM from paraffin-embedded tissue specimens and it is more effective in detecting NTM with TB PCR.
\end{abstract}

Keywords: NTM, TB PCR, TB/NTM PCR, Paraffin-embedded tissues

This is an Open Access article distributed under the terms of the Creative Commons Attribution Non-Commercial License (http://creativecommons.org/licenses/by-nc/3.0) which permits unrestricted non-commercial use, distribution, and reproduction in any medium, provided the original work is properly cited.

Copyright () 2014 The Korean Society for Clinical Laboratory Science. All rights reserved.
Corresponding author: Hye-Young Kim Department of Clinical Laboratory Science, Shinsung University, Dangjin 343-861, Korea Tel: 82-41-350-1407

E-mail:khy@shinsung.ac.kr

Received: May 19, 2014

Revised: June 23, 2014

Accepted: June 25, 2014

\section{서 론}

결핵은 인류 역사상 가장 많은 생명을 잃게 한 전염성 감염질환 으로서 지금도 세계인구의 약 $1 / 3$ 이 결핵균에 감염되어 있으며, 매 초 1 명의 비율로 새로 감염되고 있는 실정이다. 2010년 세계보건기 구(WHO)에서 발간한 Global tuberculosis control report에 따르 면 우리나라는 인구 10 만명 당 결핵발생률이 90명, 사망률이 8.3명 으로 34 개 $\mathrm{OECD}$ 가입국가 중 가장 높은 것으로 나타났으며, 법정 전염병 중 유병률 및 사망률 1 위로 전염성질환에 의한 사망원인의 $50 \%$ 이상이라고 보고되고 있다(World Health Organization, 2011, 김, 2012).

결핵균감염 진단방법으로 대한 결핵 및 호흡기학회에서는 항산 균 도말검사 결과 양성인 경우를 폐결핵 진단기준 방법으로 제시하 고 있다(Koh 등, 2008). 하지만 항산균 도말검사법이 간단하고, 신 속하다는 장점이 있는 반면 민감도와 특이도가 낮고 결핵균과 비결 핵성항산균(nontuberculous mycobacteria, NTM)의 감별이 어 렵다는 제한점 있으며, 결핵의 유병률이 낮거나 NTM 동정률 및 감
염증이 많은 지역에서는 위양성의 가능성이 높아진다는 연구 보고 가 있다(Koh 등, 2003). 이에 가장 확실한 진단방법으로 균수가 적 어도 검출이 가능하고 약제감수성검사도 할 수 있는 배양법이 사용 되고 있지만 배양시간이 오래 걸린다는 문제점 때문에 최근에는 결 핵균 중합효소연쇄반응법(polymerase chain reaction test for M. tuberculosis, TB-PCR)이 널리 사용되고 있다(윤 등, 2010). 하 지만 오염에 의한 위양성의 문제점과 NTM을 검출할 수 없다는 단 점이 보고되었다(Balasingham 등, 2009).

최근에는 미국, 유럽, 일본 등에서 후천성 면역겹핍증 등 면역기 능 저하 환자에서 발생하는 파종성감염과 기저질환이 없는 정상면 역상태인 성인에서 NTM 폐질환 증가로 관심이 집중되고 있다 (Johansen 등, 2002). NTM은 자연환경에 널리 분포되어 있기 때 문에 임상 검체로부터 분리되어도 기회주의 감염균으로 간주되어 병원성여부를 판단하기가 힘들다(Peter 등, 2008;Mori, 2001). 그 리고 일반적으로 결핵균에 유효하다고 알려진 항결핵제들이 NTM 에는 효과가 없는 경우가 있으며, NTM의 종류에 따라 치료가 다른 경우가 많아 실제 치료효율이 높지 않다는 점이 우려해야할 부분이 
다(Phillips와 von Reyn, 2001). 그러므로 결핵균과 NTM을 신속 하고 정확하게 구별할 수 있는 검사법의 필요성에 대한 보고가 증 가하고 있다(Hwang 등, 2011).

현재 임상에서는 결핵 진단을 위한 검체로 체액, 객담, 기관지 세 척액 등이 사용되고 있으며, 이들 검체를 이용하여 TB-PCR 검사가 진행되고 있으나(Piersimoni와 Scarparo, 2003), 폐외 결핵인 경 우에는 장기와 조직에서 병변이 나타나기 때문에 반드시 조직검사 가 이루어진다. 그리고Jordaan 등(1996)은 파라핀 조직에서 항산 성염색에서 음성인 검체 중 $\mathrm{PCR}$ 의 양성이 $16.7 \%$ 로 보고하였으며, Arnold 등(1988)은 PCR 검사법이 민감도 83\%, 특이도 98\%로 보 고된바 있다. 이에 본 연구는 결핵이 의심되는 검체 중 파라핀 포매 조직을 검체로 사용하여 TB-PCR를 진행하였으며, 최근 임상 검체 에서 검출 빈도가 높은 NTM을 신속하고 정확하게 감별하기 위하 여 TB/NTM PCR를 사용하여 연구를 수행한 후 TB-PCR과 $\mathrm{TB} / \mathrm{NTM}$ PCR 검사 결과를 비교 분석하여 결핵균과 NTM 감별에 대한 유용성을 알아보고자 하였다.

\section{재료 및 방법}

\section{1. 검체}

2013년 8월부터 12월까지 인천시 소재 한 대학병원에서 결핵이 의심되는 폐 25 예, 대장 35 예 생검 검체로 분자병리검사(TB PCR, $\mathrm{TB} / \mathrm{NTM} \mathrm{PCR}$ )가 의뢰된 환자 60예 파라핀 포매 조직을 검체로 사 용하였다.

\section{2. 조직학적 소견}

생검 조직은 $10 \%$ 중성포르말린에 고정 후 파라핀에 포매한 후 연속 절편하여 $\mathrm{H \& E}$ 염색을 하였다. 조직학적 소견에서 육아종, 건 락성 괴사병변, 다핵 거대세포의 유무를 400 배에서 관찰하였다.

\section{DNA 추출 및 농도 측정}

포르말린고정 파라핀 포매 조직에서 $10 \mu \mathrm{m}$ 씩 2장을 분절하여 탈파라핀한 다음 사용하였다. DNA 추출은 QIAamp DNA FFPE Tissue Kit (QIAGEN, Hilden, Germany)를 이용하였으며, 추출된 DNA를 Nano Drop (CA, USA)를 이용하여 정량하고 최종 DNA의 양을 $50 \mathrm{ng}$ 으로 맞추기 위해 추출된 DNA를 증류수로 희석하였으 며, 최종 template $\mathrm{DNA}$ 의 양은 $50 \mathrm{ng}$ 이하로 하였다.

\section{4. 조직 DNA 적절성 여부 확인}

추출한 조직 DNA의 적절성 여부를 확인하기 위해 $\beta$-globin과 $\beta$-actin에 대한 PCR을 병행하여 실시하였다. $\beta$-globin 유전자의 primer 염기서열(5' 3')은 forward GAC ACA ACT GTG TTC ACT $\mathrm{AG}$ 와 reverse $\mathrm{AGG}$ GTA GAC CAC CAG CAG C 였고, $\beta$-actin 유 전자의 primer 염기서열(5' 3')은 forward ATC ATG TTT GAG ACC TTC AA 와 reverse CAT CTC TTG CTC GAA GTC CA였고, $\mathrm{PCR}$ 조건은 $95^{\circ} \mathrm{C}$ 에서 5 분간 변성시킨 후, $94^{\circ} \mathrm{C}$ 에서 30 초, $55^{\circ} \mathrm{C}$ 에서 30 초 $72^{\circ} \mathrm{C}$ 에서 30 초주기로 35 회 시행하고 $72^{\circ} \mathrm{C}$ 에서 5 분간 연장하였다. 이에 증폭산물의 크기는 $200 \mathrm{bp}$ 였다.

\section{TB PCR}

결핵균의 유전자 IS6110를 검출하는 M.TB PCR Kit (BioCore, Seoul, Korea)를 사용하여 nested PCR (MJ Research, Germany) 을 시행하였다. IS 6110 primer를 이용한 PCR 방법으로 1차 PCR 혼합액 $16 \mu \mathrm{L}$ 에 검체 $\mathrm{DNA} 4 \mu \mathrm{L}$ 를 첨가하여 $95^{\circ} \mathrm{C}$ 에서 5 분간 변성 시킨 후, $94^{\circ} \mathrm{C}$ 에서 45 초, $68^{\circ} \mathrm{C}$ 에서 45 초, $72^{\circ} \mathrm{C}$ 에서 30 초 동안 35 회 반복 시행한 다음 $72^{\circ} \mathrm{C}$ 에서 5 분 1 차 연장 시행하였다. 2 차 $\mathrm{PCR}$ 혼합액 $18 \mu \mathrm{L}$ 에 1차 $\mathrm{PCR}$ 산물 $2 \mu \mathrm{L}$ 를 넣고 반응시킨 후 $95^{\circ} \mathrm{C}$ 에서 5 분간 변성시킨 후, $94^{\circ} \mathrm{C}$ 에서 45 초, $65^{\circ} \mathrm{C}$ 에서 45 초, $72^{\circ} \mathrm{C}$ 에서 30 초 동안 25 회 반복 시행한 다음 $72^{\circ} \mathrm{C}$ 에서 5 분 연장 시행하였다. $\mathrm{PCR}$ 반응 후 반응물 $10 \mu \mathrm{L}$ 를 $2 \%$ agarose gel에서 전기영동하여 양 성 대조군과 음성대조군을 대상으로 PCR 산물의 band를 확인하였 으며, 1차 PCR 산물은 $374 \mathrm{bp}$ 와 2차 PCR 산물은 $158 \mathrm{bp}$ 로 확인하 였으며, 이 중 $158 \mathrm{bp}$ 로 증폭되어 나온 band를 $\mathrm{TB}$ 로 판정하였다.

\section{TB/NTM PCR}

TB와 NTM을 구분할 수 있는 nested PCR 방법으로 고안된 TB/NTM PCR Kit (BioCore, Korea)는 모든 마이코박테리아를 검 출할 수 있는 $r p o B$ 유전자와 MTB complex에 존재하는 IS6110 유전자를 이용한 검사법이다. IS6110/rpoB primer를 이용한 PCR법으로 TB/NTM PCR 혼합액을 사용하였으며, TB PCR과 같 은 방법으로 실험을 진행하였다. $\mathrm{PCR}$ 반응 후 반응물 $10 \mu \mathrm{L}$ 를 $2 \%$ agarose gel에서 전기영동하여 TB와 NTM을 구분하였다. TB (IS6110) $158 \mathrm{bp}, \mathrm{NTM}(\mathrm{rpoB}) 235 \mathrm{bp}$ 로 나타나며, TB complex 양성인 경우에는 $235 \mathrm{bp}, 158 \mathrm{bp}$ 두 개의 band가 모두 증폭되거나 $158 \mathrm{bp}$ band만 증폭된다. NTM 양성인 경우 $235 \mathrm{bp}$ 만 증폭된 것 을 확인하여 판정하였다.

\section{DNA 염기서열분석법}

$\mathrm{TB} / \mathrm{NTM}$ PCR에서 NTM 양성으로 확인된 검체의 균 명을 확인 하기 위하여 BigDye Terminator v3.1 Cycle sequencing Kit를 이 용하였으며, ABI Prism 3730XL DNA analyzer (Applied Biosystems, Foster City, CA, USA)를 사용하여 분석하였다. 그리 
고 염기서열은 균 동정을 위하여 National Center for Biotechnology Information (NCBI)에서 제공하는 Basic Local Alignment Search Tool (BLAST) 프로그램을 이용하여 염기서열 을 비교하였다.

\section{결 과}

\section{TB PCR과 TB/NTM PCR}

임상 검체에서 $\mathrm{PCR}$ 검사가 의뢰된 환자 60예의 파라핀 포매 조 직을 대상으로 MTB PCR Kit와 TB/NTM PCR Kit를 이용한 검사 를 비교한 결과, TB PCR를 시행한 TB 양성 19예 검체 중 TB/NTM $\mathrm{PCR}$ 에서는 16 예(84.2\%)가 결핵균, 2 예(10.5\%) 검체에서 NTM, 1 예 $5.3 \%)$ 검체가 결핵균이 아닌 것으로 나타났다. 또한 TB PCR 결 과 결핵 음성으로 나온 검체 41 예 검체 중 $\mathrm{TB} / \mathrm{NTM} \mathrm{PCR}$ 에서 12 예 (29.3\%) 검체가 NTM, 29예(70.7\%) 검체가 결핵균이 아닌 것으로 확인되었다(Table 1)(Fig. 1, 2).

\section{DNA 염기서열 분석}

TB PCR와 TB/NTM PCR 검사법 결과 중에서 NTM으로 나온 결 과를 더 정확한 방법으로 균 명을 확인하기 위해서 $\mathrm{DNA}$ 염기서열 분석법을 진행하였다. NTM 14 예 검체의 DNA 염기서열 분석 결과

Table 1. Comparison of TB PCR and TB/NTM PCR

\begin{tabular}{ccccc}
\hline & \multicolumn{3}{c}{ TB/NTM PCR } \\
\cline { 2 - 4 } & $\begin{array}{c}\text { TB positive } \\
(\%)\end{array}$ & $\begin{array}{c}\text { NTM positive } \\
(\%)\end{array}$ & $\begin{array}{c}\text { TB/NTM } \\
\text { negative (\%) }\end{array}$ \\
\hline TB PCR & & & & \\
TB Positive & $16(84.2 \%)$ & $2(10.5 \%)$ & $1(5.3 \%)$ & 19 \\
TB Negative & $0(0 \%)$ & $12(29.3 \%)$ & $29(70.7 \%)$ & 41 \\
Total & 16 & 14 & 30 & 60 \\
\hline
\end{tabular}

TB, Mycobacterium tuberculosis; TB, Tuberculosis; NTM, nontuberculous mycobacterium; PCR, polymerase chain reaction.

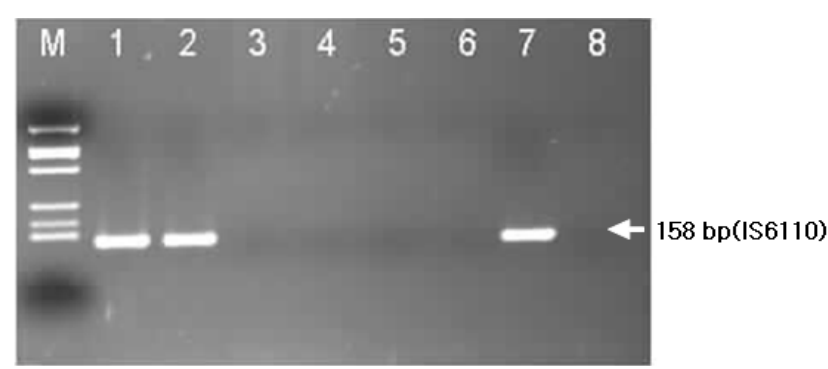

Fig. 1. Results for $2 \%$ agarose gel electrophoresis of TB PCR. lane M, BioCore Size Marker; lane 1,2, TB Positive (158 bp) Sample; lane 3,4, NTM Positive Sample; lane 5,6, Negative Sample; lane 7, Positive Control; lane 8, Negative Control.
M. gordonae 3예(21.4\%), M. avium 2예(14.3\%), M. ulcerans 1 예(7.1\%), M. interjectum 1예(7.1\%), M. farcinogenes 1예 (7.1\%), M. gilvum 1예(7.1\%), M. tokaiense 1예(7.1\%), M. fortuitum 1예(7.1\%), M. mucogenicum 1예(7.1\%)로 동정되었 으며, 미동정된 NTM이 2예(14.3\%)였다(Table 2).

\section{고 찰}

우리나라 결핵 관련 통계를 보면 신환자율이 2005년에 인구 10 만명 당 폐결핵 30,098명이었으며, 2007년부터 감소하다 2011년 부터 증가하여 2012년에는 31,075명으로 증가를 보였으며, 폐외 결핵은 2005년에 5,151명에서 2012년에는 8,470명으로 증가 추 세를 보였다. 또한 도말 양성을 결핵으로 진단한 경우 2005년 11,638명에서 2012년 12,137명으로 증가율을 보이고 있다 (Centers for Disease Control and Prevention, 2012). 이와 같은 통계는 신속하고 정확한 결핵환자의 조기 진단법의 개발과 효과적 인 치료법의 필요성을 보여 주고 있다.

국내 임상에서는 결핵균 배양검사가 특이도가 높지만 시간이 오 래 걸리는 단점이 있어 항산균 도말 검사가 민감도가 낮은 검사법

Table 2. Identification of NTM by DNA sequencing

\begin{tabular}{lc}
\hline \multicolumn{1}{c}{ Species } & No. (\%) \\
\hline M. gordonae & $3(21.4)$ \\
M. avium & $2(14.3)$ \\
M. ulcerans & $1(7.1)$ \\
M. interjectum & $1(7.1)$ \\
M. farcinogenes & $1(7.1)$ \\
M. gilvum & $1(7.1)$ \\
M. tokaiense & $1(7.1)$ \\
M. fortuitum & $1(7.1)$ \\
M. mucogenicum & $1(7.1)$ \\
Unidentifiable & $2(14.3)$ \\
Total & $14(100)$ \\
\hline
\end{tabular}

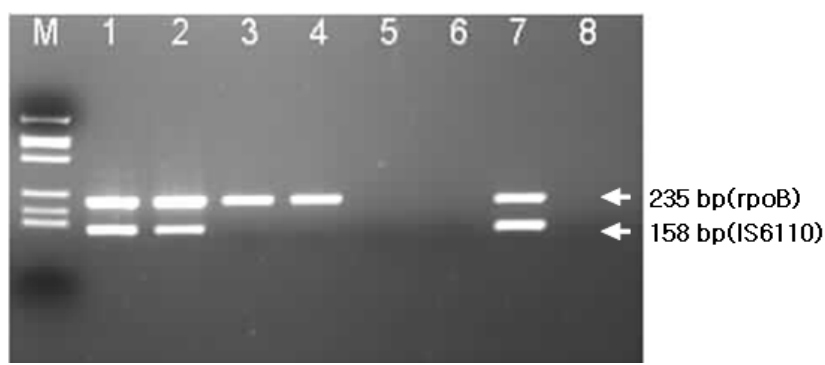

Fig. 2. Results for $2 \%$ agarose gel electrophoresis of TB/NTM PCR lane M, BioCore Size Marker; lane 1,2, TB Positive Sample (158 bp/235 bp); lane 3,4. NTM Positive Sample (235 bp); lane 5,6, Negative Sample; lane 7, Positive Control; lane 8, Negative Control. 
이지만 신속한 결과를 확인할 수 있어 이 결과에서 양성이면 결핵 으로 진단하여 항결핵제 치료를 시행하고 있으며, 도말검사에서 양 성인 경우 배양에서 NTM으로 동정되는 경우가 흔하다(Koh WJ와 Kwon, 2008; Balasingham 등, 2009).

2000년 미국 Centers for Disease Control and Prevention (CDC)은 객담 항산균 도말검사에서 양성인 경우에는 핵산증폭검 사를 시행하여 양성이면 폐결핵으로 잠정 진단하고, 만일 도말검사 양성이고, 핵산증폭검사 음성이면 검체 내에 inhibitor가 있는지 검사하여 inhibitor가 없다면 NTM에 감염 된 것으로 잠정 진단한 후 최종 진단은 배양결과로 판단하도록 권장하고 있어(Centers for Disease Control and Prevention, 2000) 미국에서는 폐결핵의 진 단에 핵산증폭검사가 상대적으로 광범위하게 이용되고 있다 (Schluger, 2001).

최근 임상에서도 항산균 도말과 배양검사 방법의 단점을 보완하 기위하여 검체에 균수가 적어도 진단이 가능하며, 높은 민감도 및 특이도와 함께 신속한 결과와 조기진단이 가능한 TB-PCR 진단법 이 많이 사용되고 있으며(Jung 등, 2008), 대부분 객담이나 기관지 세척액 검사 등을 검체로 진단에 이용하다 보니 폐 이외의 결핵인 경우에는 조직검체로 진단하기 위해 민감도가 높은 TB-PCR이 사 용되고 있다(Chawla 등, 2009). Popper 등(1994)은 파라핀 포매 조직에서 항산균 도말에서 음성인 검체 중 TB-PCR 양성이 $13.3 \%$ 로 나왔으며, 김 등(2000)에서는 $23.8 \%$ 결과로 나타났으며, 도말 양성이지만 TB-PCR에서 음성인 경우는 NTM으로 진단하는 것이 유용하다는 보고가 있었다(Yu 등, 2004). 그러나 결핵의 유병률과 발생률이 높은 국내의 경우에는 활동성 결핵균이 없는 환자의 검체 에서도 적은 수의 결핵균이 군체를 형성하여 PCR 검사 결과 위양 성으로 나타나며, 잔효 효과나 교차오염에 의해 위양성 결과가 발 생한다는 연구결과가 있었다(Araj 등, 2000; Johansen 등, 2002). 또한 $\mathrm{PCR}$ 에서 검체 내에 핵산증폭을 저해하는 물질이 있어 위음성 으로 나타났다는 보고가 있었다(Levidiotou 등, 2003).

이에 본 연구에서는 결핵이 의심되는 파라핀 포매 조직검체를 사용하여 TB PCR과 TB/NTM PCR 검사법을 시행한 결과 TB PCR 에서 결핵 양성 검체는 $31.7 \%$ (19/60예)로 나타났으며, 이 중 TB PCR와 TB/NTM PCR 결과 $84.2 \%$ (16/19예)의 양성률을 보였다. 그리고 TB PCR 음성 결과 $71.9 \%$ (41/60예), TB/NTM PCR 결과 $70.7 \%$ (29/41예)에서 음성으로 나왔으며, 29.3\% (12/41예)에서 TB/NTM PCR에서 NTM 양성결과로 확인 되었다. 그리고 TB PCR 이 양성 결과를 기준으로 할 때 TB/NTM PCR의 위음성률이 $15.6 \%$ (3/19예)이며, TB PCR이 음성일 경우는 TB/NTM PCR의 위양성 률은 29.3\% (12/41예)로 나타났다. 이와 같은 결과로 TB/NTM $\mathrm{PCR}$ 이 NTM 진단에 특이도가 높음을 확인할 수 있었다. 최근 파라
핀포매 조직에서 사용되는 $\mathrm{PCR}$ 이 유용한 반면, $\mathrm{PCR}$ primer인 IS6110, Mpb64 및 $r p o \beta$ 부위에 따른 차이 보고와 파라핀 조직이 갖는 한계나 조직에 있는 항산균의 개수나 분포 등에 따른 문제점 도 제기되고 있다((Lee 등, 2010). 그러므로 항산균 진단에 오류를 줄이기 위해서는 TB PCR과 TB/NTM PCR를 병행해서 보완적으 로 사용하는 것이 필요하다고 사료된다.

미국, 캐나다, 서유럽에선 객담에서 NTM이 분리된 환자 중 약 $40 \sim 50 \%$, 홍콩, 일본 등 아시아에서는 약 $10 \sim 20 \%$ 가 NTM 폐질환 을 일으켰다고 보고하였다(O'Brien 등, 1987; Hosker 등, 1995). 국내에서도 1981년 NTM 중 MAC (Mycobacterium avium complex) 폐질환 증례가 처음으로 보고된 후 1990년부터 이후 빠 른 속도로 증가하고 있으며, 항산균에 대한 NTM 분리 비율의 증가 하고 있다(Koh와 Kwon, 2008;Lee 등, 2009). 최근의 국내자료에 의하면 임상검체에서 분리된 항산균 중 NTM이 차지하는 비율이 20 30\%라는 보고(Koh 등, 2003)와 2002년 대학병원에서 호흡 기검체를 대상으로 항산균 도말 양성이고, 배양검사에서 양성인 균 주 중에서 NTM이 12.2\%로 확인된 결과(Lee 등, 2005)와 비교해보 면, 본 연구에서의 NTM의 검출 확률이 $23.3 \%$ (14/60예)로 더 높게 나타났다. 이와 같은 결과로 NTM의 검출률은 앞으로 증가할 것이 라 추측되며, 더우기 NTM의 진단법이 중요할 것으로 사료된다.

또한 연구에서 NTM으로 확인된 검체들을 정확하게 동정하기 위하여 염기서열 검사를 한 결과 M. gordonae $21.4 \%$ (3예)로 가장 높은 빈도를 나타냈으며, M. avium 14.3\% (2예), M. ulcerans, $M$. interjectum, $M$. farcinogenes, $M$. gilvum, $M$. tokaiense, $M$. fortuitum, M. mucogenicum은 7.1\% (1예)로 분리 동정되었다.

미국과 일본에서 NTM 폐질환의 가장 주요한 원인균은 Mycobacterium avium complex (MAC)로 60 80\% (Sakatani, 1999), 두 번째로 흔한 원인균으로 M. kansasii가 15 20\%를 차지 하며, M. abscessus, M. fortuitum, M. chelonae 등이 5\% 미만으 로 알려져 있다(O'Brien 등 1987). 1981년부터 1994년까지 14년 간 대한결핵협회 결핵연구원에 의뢰된 검체 중 총 158 검체에서 159 건의 NTM을 전통적인 생화학적 방법으로 동정한 결과 NTM 의 균주 분포는 M. avium-intracellulare 104건(65.2\%), M. fortuitum 20건(12.7\%), M. chelonae 15건(9.5\%), M. gordonae 7건(4.4\%), M. terrae 5건(3.2\%), M. scrofulaceum 3건(1.9\%), M. kansasii 2건(1.3\%), M. szulgai 2건(1.3\%), M. aviumintracellulare \& terrae 1건(0.6\%)으로 확인되었으며(정 등, 2008), 2000년까지 NTM 동정법으로 사용되다가 2001년부터는 PCR restriction fragment length polymorphism analysis (PRA) 방법을 이용하여 분류한 결과 가장 발생 빈도가 높은 균주는 MAC (65.3\%)이었고, 그 다음으로 M. abscessus (11.6\%), M. fortuitum 
complex (7.1\%), M. chelonae complex (6.3\%), M. kansasii (4.3\%), M. szulgai (0.8\%), M. celatum (0.5\%), M. scrofulaceum (0.1\%) 그리고 M. marinum $(0.06 \%)$ 순이었다(Centers for Disease Control and Prevention, 2009).

위 자료를 종합하면 NTM에 의한 폐질환에서 $\mathrm{MAC}$ 가 여전히 가 장 흔한 원인균이며, 지역에 따른 차이는 있지만 M. abscessus, M. fortuitum complex, M. chelonae complex, 그리고 M. kansasii 등이 호흡기 검체로부터 흔히 분리되는 균종임을 알 수 있다.

또한 대한 결핵협회에서 우리나라 임상환자에서 분리된 NTM 조사 결과 2009년도에 분리 동정된 MTN의 종은 M. kansasii, $M$. marinum, M. szulgai, M. gordonae, $M$. avium, $M$. intracellulare, $M$. terrae, $M$. fortuitum, M. abscessus, $M$. chelonae, $M$. malmoense, $M$. peregrinum, $M$. lentiflarum, $M$. triviale, $M$. parascrofulaceum, $M$. arupense, $M$. obuense, $M$. kumamotense, M. senuense, M. seoulense, M. paraseoulense 등 21 균종을 확인되었고, 2010년도에는 M. massilliense, M. mucogenicum, M. parafortuitum, M. celatum, M. scrofulaceum, M. aubagnense, $M$. interjectum, $M$. neoaurum, $M$. kubicae, $M$. nonchromogenicum, M. shimoidei, M. phlei, M. phocaicum, M. smegmatis, M. ulcerans, M. wolinskyi, M. xenopi, M. goodii 등 18종을 추가하였고, 2011년도에는 M. shinjukuense, M. gilvum, $M$. timonense, $M$. elephantis, $M$. bolletii 등 5종의 희귀 $\mathrm{NTM}$ 를 확보하여 총 44종이며, 향후 NTM 연구에 표준균주로 사용 할 수 있게 되었다는 보고(유 등, 2011)와 비교한 결과 본 연구에서 동정된 MTN 중 M. farcinogenes, M. tokaiense 균종은 새롭게 확 인된 균주임을 알 수 있었다.

본 연구에서 가장 높은 빈도로 분리된 M. gordonae는 객담이나 뇨 검체에서 드물지 않게 배양되지만 대개 오염균으로서 인체 감염 은 극히 드물고 후천성 면역 결핍증과 같은 면역 기능이 저하된 환 자에서 감염을 일으킬 수 있다는 보고가 있어(Wayne와 Sramek, 1992) 가장 높은 빈도로 분리된 이유가 실험실 오염과 관련 있는지 를 조사 할 필요가 있다고 사료된다. 그리고 두 번째로 분리된 $M$. avium complex 전 세계적으로 폐질환의 가장 흔한 원인균 알려져 있으며, 후천성 면역결핍증 환자뿐만 아니라 면역기능이 정상적인 사람에서도 분리된다는 보고가 있다(Primm 등, 2004). M. ulcerans는 괴사와 궤양을 발생시키는 독소를 생성하며, Buruli 궤 양, 결핵 및 나병 이후 인간에게 3 번째로 흔한 폐질환의 원인균으로 알려져 있다(Sizaire 등, 2006). 또한 M. interjectum는 1993년에 처음으로 드물게 인체감염의 원인균이라고 새롭게 보고 되었으며 (Springer 등, 1993), M. mucogenicum에 의한 인체 감염은 주로 중심정맥관 관련 패혈증 또는 외상 후 창상감염을 일으키고, 육아
종성 간염환자와 간경화 환자에서 균혈증을 일으키는 원인균으로 보고되었다(신 등, 2004). M. fortuitum은 토양과 자연수 등 자연 환경에 널리 분포하는 균으로 인체감염으로는 주로 피부나 연조직 감염, 수술 후 창상감염, 림프절염, 중심도관감염 등이 보고되어 왔 다(Brown, 1985). M. abscessus에 의한 감염의 조직학적 특징은 진피와 피하에 다형백혈구세포로 이루어진 농양과 상피양세포 및 거대세포, 괴사부위 등을 포함하는 육아종 등이 공존 하는 특징적 인 이상성(dimorphic)의 염증반응 보였으나(Swetter 등, 1993), 우리나라는 외국과 달리 M. abscessus에 의한 폐질환의 발생률이 월등히 높았고(Koh 등, 2008), 피부질환역시 증가할 것으로 추정 되기 때문에 정확한 진단과 치료적 측면의 조치가 필요하다(Ryu 등, 2005). 그리고 본 연구에서 새롭게 동정된 M. tokaiense는 드물 게 뇌하수체줄기에 육아종의 원인균으로 보고된 예가 있었으며, 면 역억제제 사용 시 증가하는 것으로 알려져 있다(Kondo 등, 2006).

\section{결 론}

본 연구에서 폐 25예, 대장 35예 생검 검체를 이용한 파라핀 포 매 조직에서 결핵균과 MTN 진단에 오류를 줄이고 효과적으로 정 확한 진단을 하기 위해서는 TB PCR과 TB/NTM PCR 검사를 병행 해서 보완적으로 사용하는 것이 필요하다고 사료된다. 또한 이전에 는 NTM 균주들을 단순히 오염균으로만 여겼지만, 최근에는 인체 감염의 원인균으로 의의가 증가하고 있어, NTM 균주의 신속하고 정확하게 진단할 수 있는 검사법의 개발이 필요하며, 국내 임상 검 체에서 새롭게 동정되는 NTM 균주에 대한 연구가 필요하다고 판 단된다.

Acknowledgements: None

Funding: None

Conflict of interest: None

\section{References}

1. Araj GF, Talhouk RS, Itani LY, Jaber W, Jamaleddine GW. Comparative performance of PCR-based assay versus microscopy and culture for the direct detection of Mycobacterium tuberculosis in clinical respiratory specimens in Lebanon. Int J Tuberc Lung Dis. 2000, 4:877-881.

2. Arnold M, Chan CY, Cheung SW, Vanhasselt CA, French GL. Diagnosis of nasopharyngeal tuberculosis by detection of tubercylostearic acid in formalin fixed, paraffin wax embedded tissue biopsy specimens. J Clin Pathol. 1988. 41:1334-1336.

3. Balasingham SV, Davidsen T, Szpinda I, Frye SA, Tønjum T. 
Molecular diagnostics in tuberculosis: basis and implications for therapy. Mol Diagn Ther. 2009, 13:137-151.

4. Brown TH. The rapidly growing mycobacteria Mycobacterium fortuitum and Mycobacterium chelonei. Infect Control. 1985, 6:283-288.

5. Centers for Disease Control and Prevention. Update: Nucleic acid amplification tests for tuberculosis. MMWR Morb Mortal Wkly Rep. 2000, 49:593-594.

6. Centers for Disease Control and Prevention. Current status of nontuberculous mycobacterial infection. Public Health Weekly Report. 2009, 2:389-407.

7. Centers for Disease Control and Prevention. Status of notified Tuberculosis in Korea, 2012. http://www.cdc.go.kr/, last visited on 14 April 2014.

8. Chawla K, Gupta S, Mukhopadhyay C, Rao PS, Bhat SS. PCR for M. tuberculosis in tissue samples. J Infect Dev Ctries. 2009, 3:83-87.

9. Hosker HS, Lam CW, Ng TK, Ma HK, Chan SL. The prevalence and clinical significance of pulmonary infection due to non-tuberculous mycobacteria in Hong Kong. Respir Med. 1995, 89:3-8.

10. Hwang SS , Oh KJ, Jang IH, Uh Y, Yoon KJ, Kim HY, et al. Evaluation of the Diagnostic Performance of the AdvanSure TB/NTM Real-Time PCR Kit for Detection of Mycobacteria. Korean J Clin Microbiol. 2011, 14:55-59.

11. Johansen IS, Thomsen VØ, Johansen A, Andersen P, Lundgren B. Evaluation of a new commercial assay for diagnosis of pulmonary and nonpulmonary tuberculosis. Eur J Clin Microbiol Infect Dis. 2002, 21:455-460.

12. Jordaan HF, Schneider JW, Schaaf HS, Victor TS, Geiger DH, Vanhelden PD. Papilonecrotic tuberculid in children. Am J Dematopathol. 1996, 18:172-185.

13. Jung CL, Kim MK, Seo DC, Lee MA. Clinical Usefulness of Real-time PCR and Amplicor MTB PCR Assays for Diagnosis of Tuberculosis. Korean J Clin Microbiol. 2008, 11:29-33.

14. Koh WJ, Kwon OJ, Yu CM, Jeon KM, Suh GY, Chung MP, et al. Recovery rate of nontuberculous mycobacteria from acid-fastbacilli smear positive sputum specimens. Tuberc Respir Dis. 2003, 54:22-32.

15. Koh WJ, Kwon OJ, Lee KS. Diagnosis and treatment of nontuberculous mycobacterial pulmonary diseases: a Korean perspective. J Korean Med Sci. 2005, 20:913-925.

16. Koh WJ, Kwon OJ, Jeon K, Kim TS, Lee KS, Park YK, et al. Clinical significance of nontuberculous mycobacteria isolated form respiratory specimens in Korea. Infec Chemother. 2008, 40:297-300.

17. Koh WJ, Kwon OJ. Diagnosis and treatment of nontuberculous mycobacterial lung disease. Korean J Med. 2008, 74:120-131.

18. Kondo A, Mori K, Iwata J, Tamura M, Yamamoto T, Nakao Y, et al. Caseous necrotic granuloma in the pituitary stalk due to nontuberculous Mycobacteria (Mycobacterium tokaiense) infection-case report. Neurol Med Chir (Tokyo). 2006, 46:80-83.

19. Lee HS, Lee HN, Im SY, Lee YS, Lee KY, Choi YJ. Comparison of Various Detection Methods of Mycobacterium Species in Formalin-Fixed Paraffin-Embedded Tissue with Chronic Granulomatous Inflammation. Korean J Pathol. 2010, 44: 259-266.
20. Lee JK, Kwon HY, Kwon JK, Lee HJ, Lee DW, Lee YJ, et al. Recovery Rate of Nontuberculous Mycobacteria and the Clinical Course of Nontuberculous Mycobacterial Pulmonary Disease at a Secondary Hospital. Tuberc Respir Dis. 2009, 67:199-204.

21. Lee JY, Choi HJ, Lee HY, Joung EY, Huh JW, Oh YM, et al. Recovery Rate and Characteristics of Nontuberculous Mycobacterial Isolates in a University Hospital in Korea. Tuberc Respir Dis. 2005, 58:385-391.

22. Levidiotou S, Vrioni G, Galanakis E, Gesouli E, Pappa C, Stefanou D. Four-year experience of use of the Cobas Amplicor system for rapid detection of Mycobacterium tuberculosis complex in respiratory and nonrespiratory specimens in Greece. Eur J Clin Microbiol Infect Dis. 2003, 22:349-356.

23. Mori T. Atypical mycobacteriosis. Nippon Rinsho. 2001, 59: 197-204.

24. O'Brien RJ, Geiter LJ, Snider DE Jr. The epidemiology of nontuberculous mycobacterial diseases in the United States: results from a national survey. Am Rev Respir Dis. 1987, 135:1007-1014.

25. Peter-Getzlaff S, Lüthy J, Böddinghaus B, Böttger EC, Springer B. Development and evaluation of a molecular assay for detection of nontuberculous mycobacteria by use of the cobas amplicor platform. J Clin Microbiol. 2008, 46:4023-4028.

26. Phillips MS and von Reyn CF. Nosocomial infections due to nontuberculous mycobacteria. Clin Infect Dis. 2001, 33:1363-1374.

27. Piersimoni C, Scarparo C. Relevance of commercial amplification methods for direct detection of Mycobacterium tuberculosis complex in clinical samples. J Clin Microbiol. 2003, 41:5355-5365.

28. Popper HH, Winter E, Hofler G. DNA of Mycobacterium tuberculosis in formalin fixed, paraffin-embedded tissue in tuberculosis and sarcoidosis detected by polymerase chain reaction. J Clin Pathol. 1994, 101:738-741.

29. Primm TP, Lucero CA, Falkinham JO. Health impacts of environmental mycobacteria. Clin Microbiol Rev. 2004, 17:98-106.

30. Ryu HJ, Kim WJ, Oh CH, Song HJ. Iatrogenic M. abscessus infection associated with acupuncture: clinical manifestations and its treatment. Int J Dermatol. 2005, 44:846-850.

31. Sakatani M. Nontuberculous mycobacteriosis: the present status of epidemiology and clinical studies. Kekkaku. 1999, 74: 377-384.

32. Schluger NW. Changing approaches to the diagnosis of tuberculosis. Am J Respir Crit Care Med. 2001, 164:2020-2024.

33. Sizaire V, Nackers F, Comte E, Portaels F. Mycobacterium ulcerans infection: control, diagnosis, and treatment. Lancet Infect Dis. 2006, 6:288-296.

34. Springer B, Kirschner P, Rost-Meyer G, Schröder KH, Kroppenstedt R, Böttger E. Mycobacterium interjectum, a new species isolated from a patient with chronic lymphadenitis. $J$ Clinical Microbiol. 1993, 31:3083-3089.

35. Swetter SM, Kindel SE, Smoller BR. Cutaneous nodules of Mycobacterium chelonae in an immunosuppressed patient with preexisting pulmonary colonization. J Am Acad Dermatol. 1993, 28:352-355.

36. Wayne LG, Sramek HA. Agents of newly recognized or infrequently encountered mycobacterial diseases. Clin Microbiol Rev. 1992, 5:1-25. 
37. World Health Organization. Global Tuberculosis Control:WHO Report. Geneva: World Health Organization, 2011.

38. Yu CM, Koh WJ, Ryu YJ, Jeon K, Choi JC, Kang EH, et al. Usefulness of PCR test for M. tuberculosis for the differentiation of pulmonary tuberculosis and nontuberculous mycobacterial lung disease in patients with smear-positive sputum. Tuberc Respir Dis. 2004, 57:528-534.

39. 김은중, 최우순, 황석연. 임상가검물과 파라핀 포매 조직에서 PCR법을 이용한 결핵균의 검출. 대한의생명과학회지. 2000, 6:55-63.

40. 김희진. 한국에서의 결핵현황. 대한내과학회지. 2012, 82:257-262.

41. 신정환, 김혜란, 이영민, 정윤성, 이선호, 김성률 등. 만성폐쇄성폐질환
이 동반된 폐렴환자에 서 발생한 Mycobacterium mucogenicum 균 혈증 1예. 대한진단검사의학회지. 2004, 24:45-48.

42. 유희경, 심명섭, 양정성, 박영길, 김창기, 김희진. 우리나라 임상환자에 서 분리된 비결핵마이코박테리아. 대한결핵 및 호흡기학회 추계학술대 회. 2011, 112:178.

43. 윤은영, 조수희, 고세일, 백종하, 김유은, 마정은 등. 결핵균과 비결핵성 항산균 검출에 Real- time PCR의 유용성. 대한결핵 및 호흡기학회지. 2010, 69:250-255.

44. 정윤성, 김성률, 장철훈, 이선호. 5년간 울산대학교병원에서 $\mathrm{HPLC}$ 법을 이용한 Mycobacteria의 동정과 균종 분포. 대한진단검사의학회지. 2008, 28:24-33. 